\title{
Alleviating aluminum toxicity in an acid sulfate soil from Peninsular Malaysia by calcium silicate application
}

\author{
A. A. Elisa ${ }^{1}$, S. Ninomiya ${ }^{1}$, J. Shamshuddin ${ }^{2}$, and I. Roslan ${ }^{2}$ \\ ${ }^{1}$ Graduate School of Agricultural and Life Sciences, The University of Tokyo, Tokyo, Japan \\ ${ }^{2}$ Department of Land Management, Faculty of Agriculture, Universiti Putra Malaysia, \\ 43400 Serdang, Selangor, Malaysia \\ Correspondence to: S. Ninomiya (snino@isas.a.u-tokyo.ac.jp)
}

Received: 11 September 2015 - Published in Solid Earth Discuss.: 19 October 2015

Revised: 27 February 2016 - Accepted: 29 February 2016 - Published: 9 March 2016

\begin{abstract}
In response to human population increase, the utilization of acid sulfate soils for rice cultivation is one option for increasing production. The main problems associated with such soils are their low $\mathrm{pH}$ values and their associated high content of exchangeable $\mathrm{Al}$, which could be detrimental to crop growth. The application of soil amendments is one approach for mitigating this problem, and calcium silicate is an alternative soil amendment that could be used. Therefore, the main objective of this study was to ameliorate soil acidity in rice-cropped soil. The secondary objective was to study the effects of calcium silicate amendment on soil acidity, exchangeable $\mathrm{Al}$, exchangeable $\mathrm{Ca}$, and $\mathrm{Si}$ content. The soil was treated with $0,1,2$, and $3 \mathrm{Mgha}^{-1}$ of calcium silicate under submerged conditions and the soil treatments were sampled every 30 days throughout an incubation period of 120 days. Application of calcium silicate induced a positive effect on soil $\mathrm{pH}$ and exchangeable $\mathrm{Al}$; soil $\mathrm{pH}$ increased from 2.9 (initial) to 3.5 , while exchangeable $\mathrm{Al}$ was reduced from 4.26 (initial) to $0.82 \mathrm{cmol}_{\mathrm{c}} \mathrm{kg}^{-1}$. Furthermore, the exchangeable $\mathrm{Ca}$ and $\mathrm{Si}$ contents increased from 1.68 (initial) to $4.94 \mathrm{cmol}_{\mathrm{c}} \mathrm{kg}^{-1}$ and from 21.21 (initial) to $81.71 \mathrm{mg} \mathrm{kg}^{-1}$, respectively. Therefore, it was noted that calcium silicate was effective at alleviating $\mathrm{Al}$ toxicity in acid sulfate, rice-cropped soil, yielding values below the critical level of $2 \mathrm{cmol}_{\mathrm{c}} \mathrm{kg}^{-1}$. In addition, application of calcium silicate showed an ameliorative effect as it increased soil $\mathrm{pH}$ and supplied substantial amounts of $\mathrm{Ca}$ and $\mathrm{Si}$.
\end{abstract}

\section{Introduction}

Soils are the key to understanding the earth system as they control the hydrological, biological, geochemical, and erosional cycles (Smith et al., 2015; Decock et al., 2015; Keesstra et al., 2012). Moreover, the soil system is damaged by millennial use and abuse of soil resources, and the soils are failing to supply humankind with goods and services due to the degradation of soil structure, loss of soil quality, and loss of soil fertility (Dai et al., 2015; Masto et al., 2015; Zhao et al., 2015; Cerda, 1998; Costa et al., 2015). Pollution is one of the triggering factors of soil degradation and it is a worldwide problem (Wang et al., 2015; Roy and Mcdonald, 2015; Mahmoud and Abd El-Kader, 2015). Therefore, this is why it is necessary to develop a new strategy to restore and rehabilitate the soils, which can be based on the use of amendments (Riding et al., 2015; Hu et al., 2015; Yazdanpanah et al., 2016; Tejada and Benitez, 2014; Prosdocimi et al., 2016).

Acid sulfate soils are widespread in Malaysia, occurring almost exclusively along its coastal plain (Shamshuddin and Auxtero, 1991; Shamshuddin et al., 1995; Muhrizal et al., 2006; Enio et al., 2011). In these areas, the alluvial sediments are intermittently inundated by seawater during low and high tides. These soils are dominated by pyrite with high acidity (soil $\mathrm{pH}<3.5$ ) (Shamshuddin, 2006) and are produced when the pyrite-laden soils in the coastal plains are opened up for crop production and/or development. This scenario leads to the release of large amounts of $\mathrm{Al}$ into the soil environment (Shamshuddin et al., 2004), which affects crop growth. For example, it affects oil palm growth (Auxtero and Shamshuddin, 1991) and cocoa production (Shamshuddin et al., 2004). 
In Peninsular Malaysia, acid sulfate soils are used for rice cultivation with mixed success. At times, rice cultivation in these soils is successful; but most often, the rice yield each season is very low $\left(<2 \mathrm{tha}^{-1}\right)$. Amelioration practices with ground magnesium lime (GML) and/or basalt have shown improvements of up to $3.5 \mathrm{tha}^{-1}$ in rice yield (average per season).

The application of soil amendments to acid sulfate soil is a common approach for improving fertility. Suswanto et al. (2007), Shamshuddin et al. (2009), Shazana et al. (2013), Elisa et al. (2014), Fernandez-Sanjurjo (2014), Rabileh et al. (2015), and Rosilawati et al. (2014) reported that the infertility of acid sulfate soils can be ameliorated by application of lime, basalt, gypsum, biochar, controlled-release fertilizer, organic fertilizer, and/or their combination at an appropriate rate. Application of these ameliorants increased soil $\mathrm{pH}$ and reduced $\mathrm{Al}$ toxicity, resulting in improved rice growth. In addition to these improvements, these ameliorants also supply calcium $(\mathrm{Ca})$ and magnesium $(\mathrm{Mg})$, which are needed for crop growth and development.

Besides $\mathrm{Ca}$ and $\mathrm{Mg}$, silicon ( $\mathrm{Si}$ ) is also important for rice growth. It has a positive effect on the growth of crops such as tomato (Peaslee and Frink, 1969), barley, and soybean (Hodson and Evans, 1995; Nolla et al., 2006), and many others (Liang et al., 2007; Nolla et al., 2012). The application of Si may reduce the severity of fungal diseases such as blast and sheath blight of rice (Farnaz et al., 2012); powdery mildew of barley, wheat, cucumber, muskmelon, and grape leaves; and vermin damage of rice by plant hopper (Crooks and Prentice, 2012; Ma et al., 2001; Menzies et al., 1992; Bowen et al., 1992; Datnoff et al., 2001). In addition, Si can effectively reduce Al toxicity (Barcelo et al., 1993). Calcium silicate application could be a source of Si for soils. This material is available in Peninsular Malaysia. Therefore, this study is relevant because calcium silicate could be used to alleviate Al toxicity of soil from the Merbok granary area located in the northern state of Kedah, Peninsular Malaysia. Certain regions of the rice cultivation area are classified as acid sulfate soils and the average rice yield in these areas is less than $2 \mathrm{tha}^{-1}$ season $^{-1}$. This is due to high soil acidity, Al toxicity, and/or rice blast disease ( $M$. grisea). Therefore, the main objective of this study was to ameliorate soil acidity in the rice-cropped soils of this area. The secondary objective was to study the effects of calcium silicate amendment on soil acidity, exchangeable $\mathrm{Al}$, exchangeable $\mathrm{Ca}$, and $\mathrm{Si}$ content.

\section{Materials and methods}

\subsection{Soil type, treatments, and experimental design}

The experiment was conducted at the Field 2 Glasshouse at Universiti Putra Malaysia, Serdang, Malaysia. The soil used in this study was obtained from Merbok, Kedah, Peninsular Malaysia. The soil sampling site was a rice-cropped area and the sampling was performed 1 month prior to rice cultivation (dry conditions). A composite soil sample of approximately $2500 \mathrm{~g}$ was taken from $0-15 \mathrm{~cm}$ depth using an auger. The sample was taken within a 0.5 ha region of the rice-cropped area. Afterward, the soil was crushed, passed through a $2 \mathrm{~mm}$ sieve, and mixed thoroughly prior to incubation.

Five hundred grams of soil was used to fill a plastic pot, which was then incubated for 120 days. The treatments included 0 (CS0), 1 (CS1), 2 (CS2), and 3 (CS3) $\mathrm{Mg} \mathrm{ha}^{-1}$ of calcium silicate, with three replications. These were arranged in a completely randomized design (CRD). The total number of samples was 48 (4 treatments $\times 3$ replications $\times 4$ sampling times). Twelve pots were sampled every 30 days throughout the incubation period, i.e., the sampling times were at 30 days (D30), 60 days (D60), 90 days (D90), and 120 days (D120) of incubation and corresponded to the vegetative, reproductive, flowering, and maturity phases of rice growth, respectively. The calcium silicate $\left(\mathrm{CaSiO}_{3}\right)$ used in this experiment was obtained from Kaolin (Malaysia) Sdn. Bhd., Malaysia. This calcium silicate had the following composition: $\mathrm{SiO}_{2}=40-55$, calcium (as $\mathrm{CaO})=40-50, \mathrm{Al}_{2} \mathrm{O}_{3}=$ below $1.5, \mathrm{MgO}=$ below 3 , iron (as $\mathrm{Fe}_{2} \mathrm{O}_{3}$ ) = below $1 \%$, and $\mathrm{pH}=8.54$.

The soils were mixed thoroughly with the added calcium silicate prior to the addition of water. Tap water was added regularly and the water levels were maintained at approximately $5 \mathrm{~cm}$ (height) above the soil surface. The composition of the tap water in relation to phosphorus $(\mathrm{P})$, potassium $(\mathrm{K})$, aluminum $(\mathrm{Al})$, calcium $(\mathrm{Ca})$, iron $(\mathrm{Fe})$, magnesium $(\mathrm{Mg})$, and silicon ( $\mathrm{Si}$ ) was $0.74,10.62,0.14,19.78,0.03,1.00$, and $5.18 \mathrm{mg} \mathrm{L}^{-1}$, respectively. The $\mathrm{pH}$ of the tap water used was 7.37 .

\subsection{Soil analyses}

Soil samples were air-dried, ground, and passed through a $2 \mathrm{~mm}$ sieve prior to chemical analyses. Soil $\mathrm{pH}$ was determined in water at a ratio of $1: 2.5$ (soil/distilled water) using a glass electrode $\mathrm{pH}$ meter. Total $\mathrm{C}, \mathrm{N}$, and $\mathrm{S}$ were determined using a Leco CNS analyzer. Cation exchange capacity (CEC) was determined using $1 \mathrm{M} \mathrm{NH}_{4} \mathrm{OA}_{\mathrm{c}}$ at $\mathrm{pH} 7$ (Chapman, 1965). Exchangeable $\mathrm{Ca}, \mathrm{Mg}, \mathrm{K}$, and $\mathrm{Na}$ were determined using $1 \mathrm{~N} \mathrm{NH}_{4} \mathrm{Cl}$ (Ross and Ketterings, 1995; Shamshuddin, 2006). To achieve this, $2 \mathrm{~g}$ of air-dried soil was placed in a 50 centrifuge tube and $20 \mathrm{~mL} 1 \mathrm{~N} \mathrm{NH}_{4} \mathrm{Cl}$ was added. The sample was shaken for $2 \mathrm{~h}$ on an end-to-end shaker at $150 \mathrm{rpm}$, followed by centrifugation at $2500 \mathrm{rpm}$ for $15 \mathrm{~min}$. The extract was passed through filter paper into a $50 \mathrm{~mL}$ plastic vial. The exchangeable $\mathrm{Ca}, \mathrm{Mg}, \mathrm{K}$, and $\mathrm{Na}$ in the extract were determined by inductively coupled plasma optical emission spectroscopy (ICP-OES). Exchangeable Al was determined by extracting $5 \mathrm{~g}$ of soil with $50 \mathrm{~mL}$ of $1 \mathrm{M}$ $\mathrm{KCl}$. The mixture was shaken for $30 \mathrm{~min}$ and the extracted $\mathrm{Al}$ was analyzed by ICP-OES. Extractable $\mathrm{Fe}, \mathrm{Cu}, \mathrm{Zn}$, and $\mathrm{Mn}$ were extracted using extracting agent $(0.05 \mathrm{~N} \mathrm{HCl}$ and 


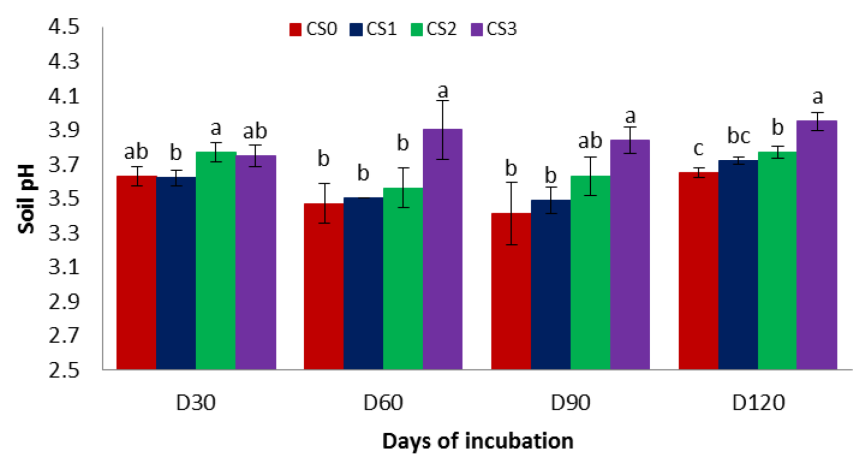

Figure 1. Effects of calcium silicate application on soil $\mathrm{pH}$ under submerged conditions. Means marked with the same letter for each incubation day are not significantly different at $p<0.05$ (Tukey's test).

$0.025 \mathrm{~N} \mathrm{H}_{2} \mathrm{SO}_{4}$ ). To achieve this, $5 \mathrm{~g}$ of air-dried soil was shaken with $25 \mathrm{~mL}$ of extracting agent for $15 \mathrm{~min}$. The extract was passed through filter paper and was used to determine $\mathrm{Fe}, \mathrm{Cu}, \mathrm{Zn}$, and $\mathrm{Mn}$ by atomic absorption spectrometry (AAS). Additionally, $0.01 \mathrm{M} \mathrm{CaCl}_{2}$ was used to extract plantavailable Si from the soil. For this, $2 \mathrm{~g}$ of soil was shaken for $16 \mathrm{~h}$ with $20 \mathrm{~mL} \mathrm{CaCl}_{2}$ extractant in a $50 \mathrm{~mL}$ centrifuge tube on an end-to-end shaker. The sample was centrifuged at $2000 \mathrm{rpm}$ for $10 \mathrm{~min}$ before the supernatant was filtered and analyzed for Si (Datnoff et al., 2001) using ICP-OES.

\subsection{Statistical analysis}

Statistical analysis for means comparison was performed using Tukey's test in SAS version 9.2 (SAS Institute Inc., Cary, NC).

\section{Results}

\subsection{Initial soil chemical characteristics}

Initial soil $\mathrm{pH}$ and exchangeable $\mathrm{Al}$ were 2.90 and $4.26 \mathrm{cmol}_{\mathrm{c}} \mathrm{kg}^{-1}$, respectively. Exchangeable $\mathrm{Ca}, \mathrm{Mg}, \mathrm{K}$, and $\mathrm{Na}$ were $1.68,2.61,0.55$, and $2.61 \mathrm{cmol}_{\mathrm{c}} \mathrm{kg}^{-1}$, respectively. Total C, N, and S were 3, 0.2 , and $0.13 \%$, respectively. At the site where the soil was sampled, rice is normally grown twice per year and the straw is often left to rot on the paddy field. The decomposition of the rice straw, to some extent, contributed to the increased C content and CEC of the soil. In this study, the CEC of the soil was $18.12 \mathrm{cmol}_{\mathrm{C}} \mathrm{kg}^{-1}$. The values for extractable $\mathrm{Fe}, \mathrm{Cu}, \mathrm{Zn}, \mathrm{Mn}$, and $\mathrm{Si}$ prior to incubation were $1118.6,0.23,0.96,1.60$, and $21.21 \mathrm{mg} \mathrm{kg}^{-1}$, respectively.

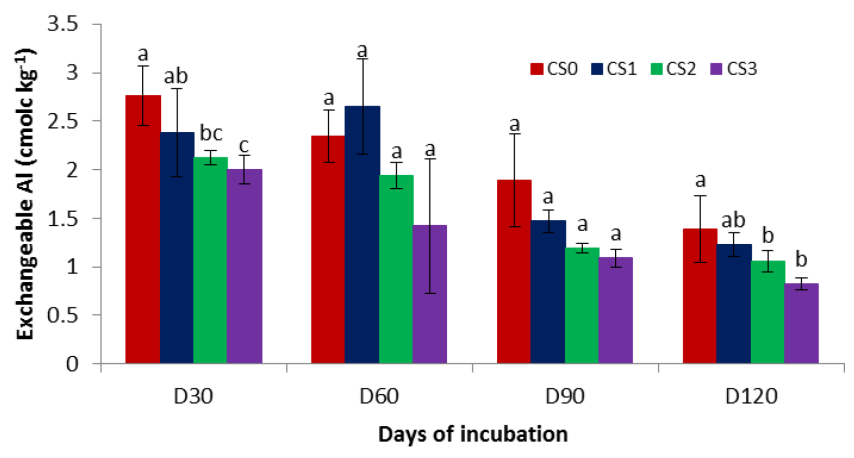

Figure 2. Effects of calcium silicate application on exchangeable aluminum. Means marked with the same letter for each incubation day are not significantly different at $p<0.05$ (Tukey's test).

\subsection{Effect of calcium silicate on soil pH}

Figure 1 shows the effect of calcium silicate application on soil $\mathrm{pH}$ under submerged conditions. It shows that soil $\mathrm{pH}$ increased in line with the incremental increases in the calcium silicate application rate. The highest soil $\mathrm{pH}$ increase was from 2.90 (initial) to 3.95 due to the application of $3 \mathrm{Mg} \mathrm{ha}^{-1}$ calcium silicate. After 30 days of incubation (D30), soil $\mathrm{pH}$ of CS2 was significantly higher than that of CS1, with values of 3.77 and 3.62, respectively. Treatment CS3 was significantly higher in terms of soil $\mathrm{pH}$ compared with CS0, CS1, and CS2 at D60; CS0 and CS1 at D90; and CS0, CS1, and CS2 at D120, showing values of 3.90, 3.84, and 3.95, respectively.

\subsection{Effect of calcium silicate on exchangeable Al}

Figure 2 shows the effect of calcium silicate application on exchangeable Al. It shows that as the calcium silicate rate increased, the exchangeable $\mathrm{Al}$ decreased from 4.26 to $0.82 \mathrm{cmol}_{\mathrm{c}} \mathrm{kg}^{-1}$. This is a $74 \%$ decrease in exchangeable $\mathrm{Al}$ in the acid sulfate soil due to the application of calcium silicate. At 30 and 120 days of incubation, exchangeable $\mathrm{Al}$ content in the soil treated with 2 and $3 \mathrm{Mg} \mathrm{ha}^{-1}$ of calcium silicate had significantly decreased compared to that in the untreated soil. However, there was no significant effect of calcium silicate on exchangeable $\mathrm{Al}$ after 60 and 90 days of incubation.

\subsection{Effect of calcium silicate on exchangeable calcium}

Figure 3 show that the application of calcium silicate increased exchangeable $\mathrm{Ca}$. There was a significant effect among the treatments after 30 days of incubation. At 60, 90, and 120 days of incubation, soil treated with 2 and $3 \mathrm{Mgha}^{-1}$ of calcium silicate had significantly increased soil-exchangeable Ca compared with both untreated soil and soil treated with $1 \mathrm{Mgha}^{-1}$ of calcium silicate. 


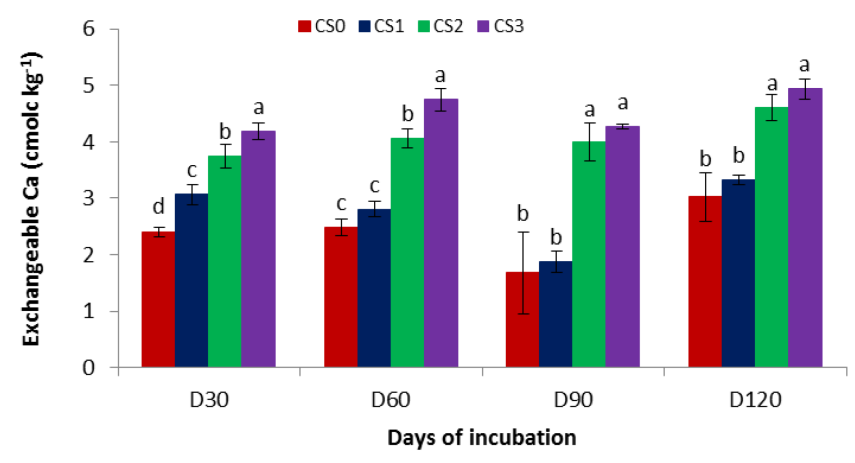

Figure 3. Effects of calcium silicate application on exchangeable calcium. Means marked with the same letter for each incubation day are not significantly different at $p<0.05$ (Tukey's test).

\subsection{Effect of calcium silicate on silicon content}

Application of calcium silicate increased the Si content of the soil, as shown in Fig. 4, from 14 to $74 \%$. At 30 days of incubation, soil treated with 2 and $3 \mathrm{Mg} \mathrm{ha}^{-1}$ of calcium silicate had a significantly increased $\mathrm{Si}$ content compared with both untreated soil and soil treated with $1 \mathrm{Mg} \mathrm{ha}^{-1}$ of calcium silicate. At 60 days of incubation, the Si content increased significantly for soil treated with 2 and $3 \mathrm{Mg} \mathrm{ha}^{-1}$ of calcium silicate compared with the soil treated with $1 \mathrm{Mg} \mathrm{ha}^{-1}$ of calcium silicate. The Si content of the soil continued to increase at 90 days of incubation; in the soil treated with $1 \mathrm{Mg} \mathrm{ha}^{-1}$ calcium silicate, it was significantly increased compared to the $2 \mathrm{Mg} \mathrm{ha}^{-1}$ treatment. However, no significant effect was observed among the treatments after 120 days of incubation.

\section{Discussion}

From this study, it was found that calcium silicate can neutralize $\mathrm{H}^{+}$ions in soil, as noted by the $\mathrm{pH}$ increase in acid sulfate soils upon calcium silicate application (Fig. 1). Similar findings have been found by Smyth and Sanchez (1980) and Fiantis et al. (2002). These authors attributed their results to the $\mathrm{OH}^{-}$released from colloidal surfaces during the adsorption of the silicate ions. Due to the application of calcium silicate, soil $\mathrm{pH}$ increased significantly from 2.90 (initial) to 3.41-3.95.

During the incubation period, there was a strong relationship between calcium silicate and soil pH at D30 $\left(R^{2}=\right.$ $0.77)$, D60 $\left(R^{2}=0.77\right)$, D90 $\left(R^{2}=0.84\right)$, and D120 $\left(R^{2}=\right.$ $0.92)$. The increasing correlation coefficient over time was related to the increasing capacity of the soil to adsorb silicate anions.

It was observed that the soil $\mathrm{pH}$ was slightly lower for CSO, CS1, and CS2 at D60 and D90 compared to that at D30 and D120. The decrease in soil $\mathrm{pH}$ is believed to be due to the release of protons as pyrite in the soil was oxidized during the incubation period. Shamshuddin et al. (2004) reported

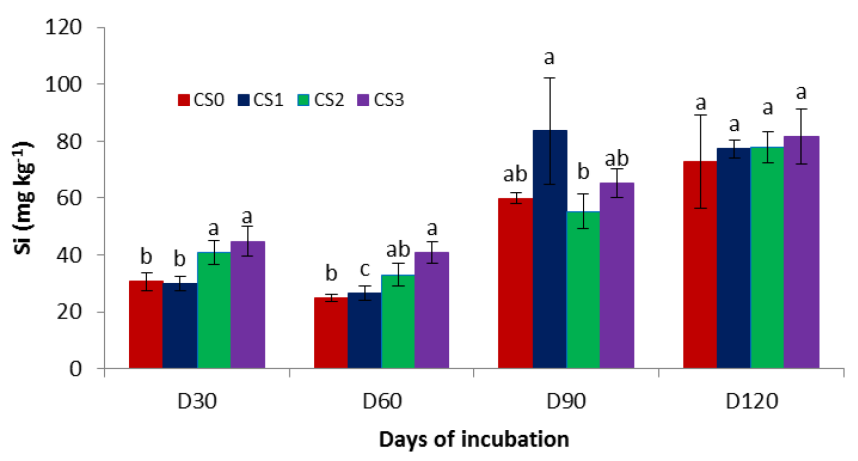

Figure 4. Effects of calcium silicate application on silicon content. Means marked with the same letter for each incubation day are not significantly different at $p<0.05$ (Tukey's test).

that after 12 weeks of incubation, soil $\mathrm{pH}$ in the $\mathrm{Cg}$ horizon of acid sulfate soil was lowered by 1 unit. The results from the current study are consistent with those from other studies on acid sulfate soils (Shamshuddin and Auxtero, 1991; Shamshuddin et al., 1995, 2014). The oxidation of pyrite, which produces acidity, may have taken place according to the following reactions outlined by van Breemen (1976):

$2 \mathrm{FeS}_{2(\mathrm{~s})}+7 \mathrm{O}_{2(\mathrm{aq})}+2 \mathrm{H}_{2} \mathrm{O} \rightarrow \mathrm{Fe}_{(\mathrm{aq})}^{2+}+4 \mathrm{SO}_{4}^{2-}+4 \mathrm{H}_{(\mathrm{aq})}^{+}$.

Further oxidation of $\mathrm{Fe}^{2+}$ to $\mathrm{Fe}^{3+}$ oxide could also promote acidity:

$2 \mathrm{Fe}_{(\mathrm{aq})}^{2+}+1 / 2 \mathrm{O}_{2(\mathrm{aq}, \mathrm{g})}+\mathrm{H}_{2} \mathrm{O} \rightarrow \mathrm{Fe}_{2} \mathrm{O}_{3(\mathrm{~s})}+4 \mathrm{H}_{(\mathrm{aq})}^{+}$.

As the soil $\mathrm{pH}$ increased due to the application of calcium silicate, exchangeable Al decreased to below the critical level for rice growth $\left(2 \mathrm{cmol}_{\mathrm{c}} \mathrm{kg}^{-1}\right)$. This is consistent with the findings of Hiradate et al. (2007). Figure 2 shows the effect of the treatments on exchangeable Al. It shows that exchangeable Al decreased significantly among the treatments after 30 days and 120 days. After 30 days of incubation, the exchangeable Al contents of treatments CS2 and CS3 were significantly reduced compared to $\mathrm{CS} 0$, which was near the critical level of $2 \mathrm{cmol}_{\mathrm{c}} \mathrm{kg}^{-1}$. It is also shown that exchangeable $\mathrm{Al}$ decreased further as the incubation period was further extended. Figure 5 shows the relationship between exchangeable $\mathrm{Al}$ and soil $\mathrm{pH}$, where the lines for D60, D90, and D120 are below the line for D30. This implies that a prolonged incubation period would further reduce the exchangeable $\mathrm{Al}$ content. The decrease in $\mathrm{Al}$ could also be due to the precipitation of $\mathrm{Al}$ in the form of inert $\mathrm{Al}$ hydroxides. The exchangeable $\mathrm{Al}$ content was reduced to below the critical level of $2 \mathrm{cmol}_{\mathrm{c}} \mathrm{kg}^{-1}$ at D90 and D120.

The reduction in exchangeable $\mathrm{Al}$ is explained as follows. It is possible that soil $\mathrm{Al}$ can be reduced by the reactions of Si-rich compounds. By such reactions, Datnoff et al. (2001) postulated five mechanisms of Al reduction: (1) monosilicic acids increase soil pH (Lindsay, 1979); (2) monosilicic acids are adsorbed on $\mathrm{Al}$ hydroxides, reducing their 


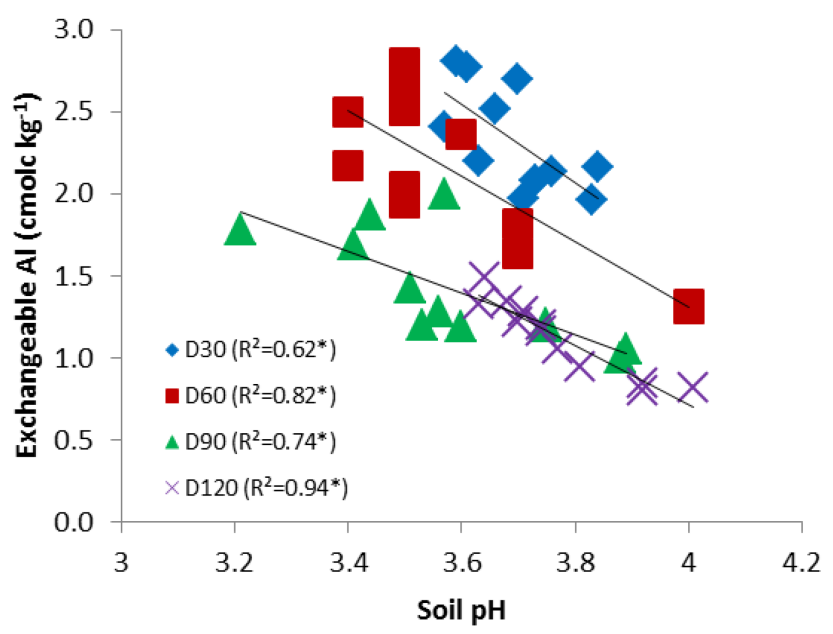

Figure 5. Relationship between exchangeable $\mathrm{Al}$ and soil $\mathrm{pH}$ (* $^{*}$ $p<0.05)$.

mobility (Panov et al., 1982); (3) soluble monosilicic acid forms slightly soluble substances with $\mathrm{Al}$ ions (Lumsdon and Farmer, 1995); (4) mobile Al is strongly adsorbed on silica surfaces (Schulthess and Tokunaga, 1996); and (5) mobile silicon compounds increase plant tolerance to Al (Rahman et al., 1998). All of these mechanisms may work simultaneously, with one perhaps prevailing under certain soil conditions (Dantoff et al., 2001).

The silicate anion can also neutralize $\mathrm{H}^{+}$in the soil solution. As the silicate anion captures $\mathrm{H}^{+}$ions, it forms monosilicic acid $\left(\mathrm{H}_{4} \mathrm{SiO}_{4}\right)$, as shown in the equation below:

$$
\begin{aligned}
& 2 \mathrm{CaSiO}_{3}+4 \mathrm{H}^{+} \\
& +2 \mathrm{H}_{2} \mathrm{O} \rightarrow \mathrm{Ca}^{2+}+2 \mathrm{H}_{4} \mathrm{SiO}_{4} \text { (monosilicic acid). }
\end{aligned}
$$

Monosilicic acid could complex with $\mathrm{Al}^{3+}$ in the soil solution to form nontoxic aluminosilicate and hydroxylaluminosilicate compounds, which precipitate in the root zone. This reaction would reduce Al toxicity in rice grown on acid sulfate soils treated with calcium silicate (Hodson and Evans, 1995; Miranda, 2012).

Furthermore, the application of calcium silicate to the acid sulfate soil showed an immediate ameliorative effect, i.e., the Ca content increased from 1.68 (initial) to above the critical level of $2 \mathrm{cmol}_{\mathrm{c}} \mathrm{kg}^{-1}$ (Palhares de Melo et al., 2001) at D30. Increasing the rate of calcium silicate increased the $\mathrm{Ca}$ content of the soil significantly (Fig. 3). For treatment CS3, exchangeable $\mathrm{Ca}$ increased significantly compared to CSO and CS1 throughout the incubation period, with increases of $42.48,47.78,60.65$, and $38.66 \%$ after $30,60,90$, and 120 days, respectively. However, no significant difference was observed between treatments CS2 and CS3 at D90 and D120.

In the current study, the Si content prior to the incubation was $21.21 \mathrm{mg} \mathrm{kg}^{-1}$; the critical soil Si concentration for crop production is $40 \mathrm{mg} \mathrm{kg}^{-1}$ (Dobermann and Fairhurst,

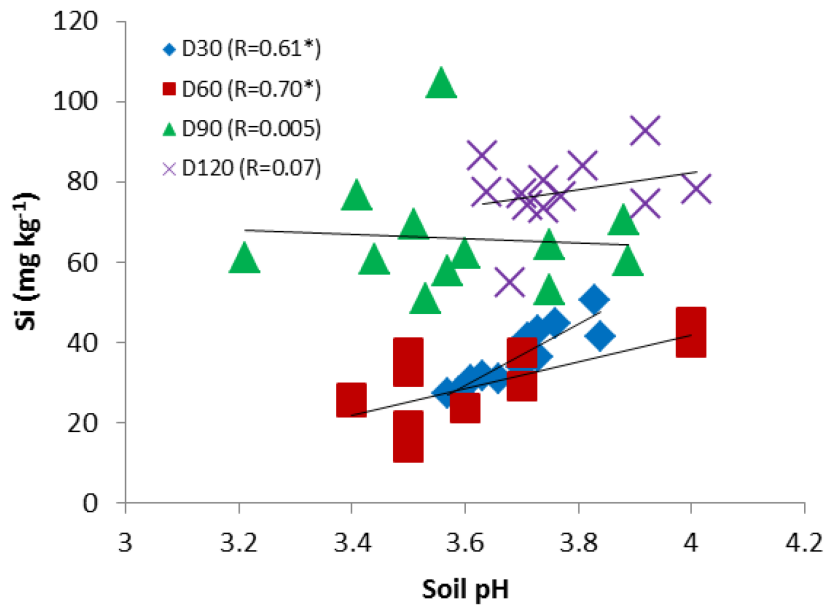

Figure 6. Relationship between $\mathrm{Si}$ content and soil $\mathrm{pH}$ throughout the incubation period $(* p<0.05)$.

2000). Figure 4 shows the effect of calcium silicate application on $\mathrm{Si}$ content. At D30, the Si content in treatments CS2 and CS3 was significantly higher than in treatments CS0 and CS1. At D60, treatment CS3 increased the Si content significantly compared to that of CSO and CS1, with a value of $40.81 \mathrm{mg} \mathrm{kg}^{-1} \mathrm{Si}$. In all treatments at D90 and D120, the Si content of the soil surpassed the deficiency level. At D90, the Si content of treatment CS1 was significantly higher than that of CS2, with a value of $83.53 \mathrm{mg} \mathrm{kg}^{-1}$. The Si content of the soil was affected by the length of incubation, i.e., the Si content of all treatments further increased at 120 days of incubation.

When the soil $\mathrm{pH}$ increased, the Si content of the soil also increased (Fig. 6). The Si content was positively correlated with soil $\mathrm{pH}$ at D30 and D60, likely due to the dissolution of calcium silicate. The ability of the soil to adsorb $\mathrm{Si}$ was higher at D30 and D60 than at D90 and D120. There was no correlation observed at D90 and D120, even though the Si content was higher, probably because the soil-exchangeable sites became fully occupied with Si through adsorption processes. This proves that the application of calcium silicate to soil, accompanied by an increase in soil $\mathrm{pH}$, enhances the ability of soil to adsorb Si.

The positive effect of the presence of Si at D30 and D60 corresponds with the early growth stage of rice, i.e., the active tillering stage. This means that a rice plant can actively uptake Si during the tillering stage, hence improving rice growth. Figure 7 shows the relationship between the exchangeable $\mathrm{Al}$ and $\mathrm{Si}$ contents of the soil throughout the incubation period after the application of calcium silicate. The reduction in exchangeable $\mathrm{Al}$ corresponded directly with the availability of $\mathrm{Si}$ in the soil. This means that as more $\mathrm{Si}$ is available in acid sulfate soil, a reduction in the exchangeable $\mathrm{Al}$ content occurs. Exchangeable $\mathrm{Al}$ was negatively correlated with Si content in the soil at D30 $(R=0.77)$ and D60 


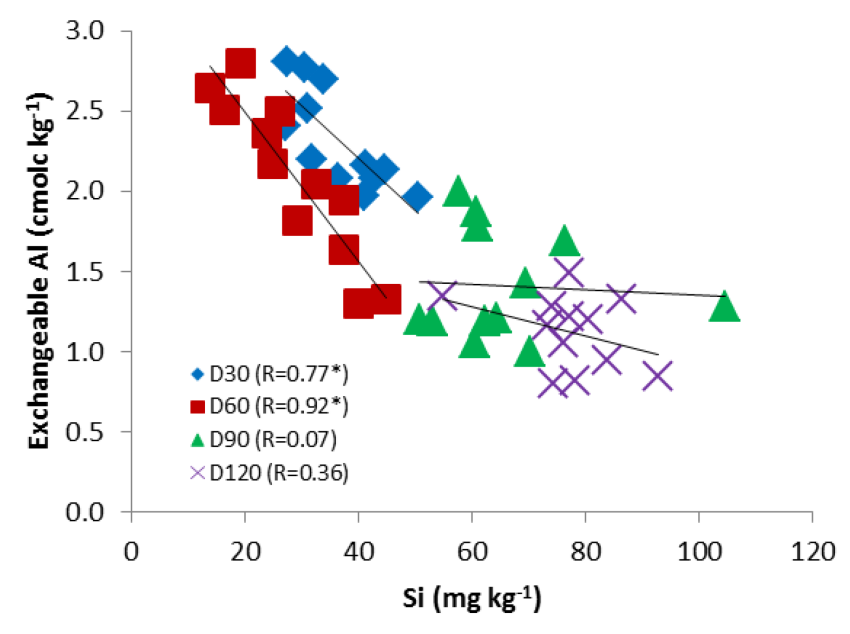

Figure 7. Relationship between exchangeable $\mathrm{Al}$ and Si content in the soil throughout the incubation period $(* p<0.05)$.

( $R=0.92$ ), whereas no correlation was observed at D90 and D120. In Fig. 7, the D60 line is below the D30 line, indicating that as the incubation period increased, the $\mathrm{Al}$ and $\mathrm{Si}$ contents showed an antagonistic pattern: Al decreased, while $\mathrm{Si}$ increased. This phenomenon indicates that when the $\mathrm{Al}$ content of the soil is low, its toxicity may not be the dominant factor inhibiting rice plant growth. On the other hand, $\mathrm{Si}$ becomes more readily available for plant uptake. Therefore, the optimal time to plant rice is 30 days after applying calcium silicate because the exchangeable $\mathrm{Al}$ is almost reduced to below the critical value of $2 \mathrm{cmol}_{\mathrm{c}} \mathrm{kg}^{-1}$. Because the $\mathrm{Si}$ content increased with incubation time, the rice plant could actively uptake $\mathrm{Si}$ for growth during active tillering.

Silicon is released from calcium silicate into the bulk soil solution and may become absorbed by plants as $\mathrm{Si}(\mathrm{OH})_{4}$. It may thus be involved in the diverse structural and dynamic aspects of plant life and crop performance. Although not considered an essential element for plant growth and development, $\mathrm{Si}$ is considered a beneficial element and is reported as being very useful to plants when they are under abiotic or biotic stress (Datnoff et al., 2001). An alleviating effect of $\mathrm{Si}$ on Al toxicity has been reported in many crops including soybean (Baylis et al., 1994), teosinte (Barcelo et al., 1993), sorghum (Hodson and Sangster, 1993), wheat, maize, cotton, and rice (Cocker et al., 1998).

A prolonged incubation of soil not treated with calcium silicate might have also influenced the changes in soil chemical characteristics. As such, CSO (untreated soil) showed an increase in soil $\mathrm{pH}$ from 2.90 (prior to incubation) to 3.63 at D30. A decrease in soil $\mathrm{pH}$ values was noted for D60 and D90, likely due to pyrite oxidation in the soil system, and no significant effect was observed among the days of incubation. Meanwhile, exchangeable Al decreased significantly with increasing incubation time. For the first 2 months, exchangeable Al was above the critical level of
Table 1. Cost of calcium silicate applied to a 1 ha area for rice production.

\begin{tabular}{|c|c|c|c|c|}
\hline Rate $\left(\mathrm{Mg} \mathrm{ha}^{-1}\right)$ & 0 & 1 & 2 & 3 \\
\hline $\begin{array}{l}\text { Price } \\
\text { (calcium silicate) }\end{array}$ & 0 & $\begin{array}{l}\text { USD } 407 \mathrm{t}^{-1} \\
=\mathrm{USD} 407\end{array}$ & $\begin{array}{l}\text { USD } 407 \mathrm{t}^{-1} \\
=\mathrm{USD} 813\end{array}$ & $\begin{array}{l}\text { USD } 407 \mathrm{t}^{-1} \\
=\text { USD } 1219\end{array}$ \\
\hline Labor & 0 & $\begin{array}{r}\text { USD } 45 \mathrm{t}^{-1} \\
=\mathrm{USD} 45\end{array}$ & $\begin{array}{r}\text { USD } 45 \mathrm{t}^{-1} \\
=\text { USD } 90\end{array}$ & $\begin{array}{l}\text { USD } 45 \mathrm{t}^{-1} \\
=\text { USD } 135\end{array}$ \\
\hline Total & 0 & USD 452 & USD 903 & USD 1354 \\
\hline
\end{tabular}

$2 \mathrm{cmol}_{\mathrm{c}} \mathrm{kg}^{-1}$ and no significant difference between D30 and D60 was observed. Exchangeable Al was significantly reduced to $1.89 \mathrm{cmol}_{\mathrm{c}} \mathrm{kg}^{-1}$ at D90, but no significant effect was observed thereafter, i.e., at D120. Application of calcium silicate significantly increased the Si content of the soil. However, no significant effect on Si content was observed between D30 and D60 or between D90 and D120. The Si content of the soil increased significantly, to $59.81 \mathrm{mg} \mathrm{kg}^{-1}$, after 90 days of incubation. The significant increase in Si was due to the hydrolysis of silicate minerals present in the acid sulfate soils. For instance, the hydrolysis of silicate is generalized in the following reaction:

Silicate $+\mathrm{H}_{2} \mathrm{O}+\mathrm{H}_{2} \mathrm{CO}_{3} \rightarrow$ base cation

$+\mathrm{HCO}_{3}^{-}+\mathrm{H}_{4} \mathrm{SiO}_{4}+$ accessory mineral.

In this reaction, the base cation would commonly be $\mathrm{Mg}^{2+}$ or $\mathrm{Ca}^{2+} ; \mathrm{H}_{2} \mathrm{CO}_{3}$ is a proton source, $\mathrm{HCO}_{3}^{-}$is bicarbonate, $\mathrm{H}_{4} \mathrm{SiO}_{4}$ is silicic acid, and gibbsite $\left[\mathrm{Al}(\mathrm{OH})_{3}\right]$ is a representative accessory mineral (Essington, 2005).

Farmers in the study area have applied GML to overcome soil fertility problems associated with $\mathrm{Al}$ toxicity. As an alternative to GML application, this study suggests that such farmers could benefit from the use of calcium silicate as a soil amendment. Therefore, the costs of the input (calcium silicate) and labor should be taken into account to better understand the feasibility of such an approach for farmers in this region. Table 1 shows the costs of applying calcium silicate to 1 ha area for rice production. The costs for calcium silicate and labor were USD 407 and USD $45 \mathrm{t}^{-1}$, respectively. The total cost (calcium silicate and labor) ranged from USD 452 to USD $1354 \mathrm{ha}^{-1}$.

\section{Conclusions}

Application of calcium silicate showed an ameliorative effect on acid sulfate soil, i.e., an increase in soil $\mathrm{pH}$, exchangeable $\mathrm{Ca}$ content, and $\mathrm{Si}$ content, and a reduction in exchangeable Al. This suggests that calcium silicate amendment is effective in alleviating Al toxicity in acid sulfate, rice-cropped soils. Furthermore, it is an affordable soil amendment, with a cost ranging from USD 452 to USD $1354 \mathrm{ha}^{-1}$. 
Acknowledgements. We would like to acknowledge Universiti Putra Malaysia and Ministry of Higher Education Malaysia for technical and financial support (under LRGS Program-Food Security: enhancing sustainable rice production).

Edited by: A. Cerdà

\section{References}

Auxtero, E. A. and Shamshuddin, J.: Growth of oil palm (Elaeis guineensis) seedlings on acid sulfate soils as affected by water regime and aluminium, Plant Soil, 137, 243-257, 1991.

Barcelo, J., Guevara, P., and Poschenriede, C.: Silicon amelioration of aluminium toxicity in teosinte (Zea mays L. ssp. Mexicana), Plant Soil, 154, 249-255, 1993.

Baylis, A. D., Gragopoulou, C., Davidson, K. J., and Birchall, J. D.: Effects of silicon on the toxicity of aluminium to soybean, Commun. Soil Sci. Plant, 25, 537-546, 1994.

Bowen, P., Menzies, J., and Ehret, D.: Soluble silicon sprays inhibit powdery mildew development on grape leaves, J. Amer. Soc. Hort. Sci., 117, 906-912, 1992.

Cerda, A.: Relationship between climate and soil hydrological and erosional characteristics along climatic gradients in Mediterranean limestone areas, Geomorphology, 25, 123-134, 1998.

Chapman, H. D.: Determination of cation exchange capacity, in: Methods of soil analysis, edited by: Black, C. A., Agronomy Monogr. 9, ASA, Madison, WI, 2, 891-900, 1965.

Cocker, K. M., Evans, D. E., and Hodson, M. J.: The amelioration of aluminium toxicity by silicon in higher plants: Solution chemistry or an in planta mechanism?, Physiol. Plantarum, 104, 608614,1998

Costa, J. L., Aparicio, V., and Cerda, A.: Soil physical quality changes under different management systems after 10 years in the Argentine humid pampa, Solid Earth, 6, 361-371, doi:10.5194/se-6-361-2015, 2015.

Crooks, R. and Prentice, P.: The importance of silicon weathered soils, In: 8th International Symposium on Plant Soil Interactions at Low pH, Bengalaru, India, 412-413, 2012.

Dai, Q., Liu, Z., Shao, H., and Yang, Z.: Karst bare slope soil erosion and soil quality: A simulation case study, Solid Earth, 6, 985-995, doi:10.5194/se-6-985-2015, 2015.

Datnoff, L. E., Snyder, G. H., and Korndörfer, G. H.: Silicon in agriculture, ISBN 978-0-444-50262-9, 8, 1-403, 2001.

Decock, C., Lee, J., Necpalova, M., Pereira, E. I. P., Tendall, D. M., and Six, J.: Mitigating $\mathrm{N}_{2} \mathrm{O}$ emissions from soil: from patching leaks to transformative action, SOIL, 1, 687-694, doi:10.5194 /soil-1-687-2015, 2015.

Dobermann, A. and Fairhurst, T.: Rice: Nutrient disorders and nutrient management, IRRI, Los Banos, 2000.

Elisa, A. A., Shamshuddin, J., Che, F. I., and Roslan, I.: Increasing rice production using different lime sources on an acid sulfate soil in Merbok, Malaysia, Pertanika J. Trop. Agric. Sci., 37, 223 247, 2014

Enio, M. S. K., Shamshuddin, J., Fauziah, C. I., and Husni, M. H. A.: Pyritization of the coastal sediments in Kelantan plains in the Malay Peninsula during the Holocene, Am. J. Agr. Biol. Sci., 6, 393-402, 2011
Essington, M. E.: Soil and water chemistry: An integrative approach, ISBN 0-203-49614-0, CRC Press, 104-127, 2005.

Farnaz, A. A., Jugah, K., Abbaz, N., Seyed, R. H. R., and Hailmi, S.: Effect of silicon on rice blast disease, Pertanika J. Trop. Agric. Sci., 35, 1-12, 2012.

Fernández-Sanjurjo, M. J., Alvarez-Rodríguez, E., Núñez-Delgado, A., Fernández-Marcos, M. L., and Romar-Gasalla, A.: Nitrogen, phosphorus, potassium, calcium and magnesium release from two compressed fertilizers: column experiments, Solid Earth, 5, 1351-1360, doi:10.5194/se-5-1351-2014, 2014.

Fiantis, D., Van Ranst, E., Shamshuddin, J., Fauziah, I., and Zauyah, S.: Effect of calcium silicate and superphosphate application on surface charge properties of volcanic soils from West Sumatra, Indonesia, Commun. Soil Sci. Plant, 33, 1887-1900, 2002.

Hiradate, S., Ma, J. F., and Matsumoto, H.: Strategies of plants to adapt to mineral stresses in problem soils, Adv. Agron., 96, 66132, 2007.

Hodson, M. J. and Evans, D.E.: Aluminum/silicon interaction in higher plants, J. Exp. Bot., 46, 161-171, 1995.

Hodson, M. J. and Sangster, A. G.: The interaction between silicon and aluminium in Sorghum bicolour (L.) Moench: Growth analysis and X-ray microanalysis, Ann. Bot.-London, 72, 389-400, 1993.

Hu, Y. L., Niu, Z. X., Zeng, D. H., and Wang, C. Y.: Soil amendment improves tree growth and soil carbon and nitrogen pools in Mongolian pine plantations on post-mining land in Northeast China, Land Degrad. Dev., 26, 807-812, 2015.

Keesstra, S. D., Geissen, V., van Schaik, L., Mosse, K., and Piranen, S.: Soil as a filter for groundwater quality, Current Opinion in Environmental Sustainability, 4, 507-516, 2012

Liang, Y. C., Sun, W. C., Zhu, Y. G., and Christie, P.: Mechanisms of silicon-mediated alleviation of abiotic stresses in higher plant: A review, Environ. Pollut., 147, 422-428, 2007.

Lindsay, W. L.: Chemical equilibria in soil, John Wiley \& Sons, New York, 1979.

Lumsdon, D. G. and Farmer, V. C.: Solubility characteristics of proto-imogolite soils: how silicic acid can de-toxify aluminium solutions, Europ. J. Soil Sci., 46, 179-186, 1995.

Ma, J. F., Miyake, Y., and Takahashi, E.: Silicon as a beneficial element for crop plants, in: Silicon in Agriculture, edited by: Datnoff, L. E., Snyder, G. H., and Korndorfer, G. H., Elsevier, the Netherlands, 17-40, 2001.

Mahmoud, E. and Abd El-Kader, N.: Heavy metal immobilization in contaminated soils using phosphogypsum and rice straw compost, Land Degrad. Dev., 26, 819-824, 2015.

Masto, R. E., Sheik, S., Nehru, G., Selvi, V. A., George, J., and Ram L. C.: Assessment of environmental soil quality around Sonepur Bazari mine of Raniganj coalfield, India, Solid Earth, 6, 811821, doi:10.5194/se-6-811-2015, 2015.

Menzies, J., Bowen, P., and Ehret, D.: Foliar application of potasium silicate reduce severity of powdery mildew on cucumber, muskmelon and zucchini squash, J. Am. Soc. Hortic. Sci., 117, 902-905, 1992.

Miranda, S. R.: Calcium and magnesium Silicate, an Alternative Choice for liming acid soil, in: 8th International Symposium on Plant Soil Interactions at Low pH, 18-22 October, 2012, Bengalaru, India, 414-415, 2012. 
Muhrizal, S., Shamshuddin, J., Fauziah, I., and Husni, M. H. A.: Changes in an iron-poor acid sulfate soil upon submergence, Geoderma, 131, 110-122, 2006.

Nolla, A., Korndorfer, G. H., and Coelho, L.: Efficiency of calcium silicate and carbonate on soybean disease control, J. Plant Nutr., 29, 2049-2052, 2006.

Nolla, A., Faria, R. J., Korndorfer, G. H., and Silva, T. R. B.: Effect of silicon on drought tolerance of upland rice, J. Food Agric. Environ., 10, 269-272, 2012.

Palhares de Melo, L. A. M., Bertioli, D. J., Cajueiro, E. V. M., and Bastos, R. C.: Recommendation for fertilizer application for soils via qualitative reasoning, Agr. Syst., 67, 21-30, 2001.

Panov, N. P., Goncharova, N. A., and Rodionova, L. P.: The role of amorphous silicic acid in solonetz soil processes, Vestnik Agr. Sci, 11, 18-32, 1982.

Peaslee, D. E. and Frink, C. R.: Influence of silicic acid on uptake of $\mathrm{Mn}, \mathrm{Al}, \mathrm{Zn}$ and $\mathrm{Cu}$ by tomatoes (Lycorpersicum esculentum) $\mathrm{L}$. grown on acid soil, Soil Sci. Soc. Am. Proc., 33, 569-571, 1969.

Prosdocimi, M., Jordan, A., Tarolli, P., Keesstra, S., Novara, A., and Cerda, A.: The immediate effectiveness of barley straw mulch in reducing soil erodibility and surface runoff generation in Mediterranean vineyards, Sci. Total Environ., 547, 323-330, 2016.

Rabileh, M. A., Shamshuddin, J., Panhwar, Q. A., Rosenani, A. B., and Anuar, A. R.: Effects of biochar and/or dolomitic limestone application on the properties of Ultisol cropped to maize under glasshouse conditions, Can. J. Soil Sci., 95, 37-47, 2015.

Rahman, M. T., Kawamura, K., Koyama, H., and Hara, T.: Varietal differences in the growth of rice plants in response to aluminium and silicon, Soil Sci. Plant Nutr., 44, 423-431, 1998.

Riding, M. J., Martin, F. L., Jones, K. C., and Semple, K. T.: Carbon nanomaterials in clean and contaminated soils: environmental implications and applications, SOIL, 1, 1-21, doi:10.5194/soil$1-1-2015,2015$

Rosilawati, A. K., Shamshuddin, J., and Fauziah, C. I.: Effects of incubating an acid sulfate soil treated with various liming materials under submerged and moist conditions on $\mathrm{pH}, \mathrm{Al}$ and $\mathrm{Fe}$, Afr. J. Agr. Res., 9, 94-112, 2014.

Ross, D. S. and Ketterings, Q.: Recommended method for determining soil cation exchange capacity, Newark: College of Agriculture, University of Delaware, 1995.

Roy, M. and Mcdonald, L. M.: Metal uptake in plants and health risk assessments in metal-contaminated smelter soils, Land Degrad. Dev., 26, 785-792, 2015.

Schulthess, C. P. and Tokunaga, Y.: Metal and pH effects on adsorption of poly (vinyl alcohol) by silicon oxide, Soil Sci. Soc. Am. J., 60, 92-98, 1996.

Shamshuddin, J.: Acid Sulfate Soil in Malaysia, UPM Press, Serdang, 2006.

Shamshuddin, J. and Auxtero, E. A.: Soil solution composition and mineralogy of some active acid sulfate soils in Malaysia as affected by laboratory incubation with lime, Soil Sci., 152, 365$376,1991$.
Shamshuddin, J., Jamilah, I., and Ogunwale, J. A.: Formation of hydroxyl-sulfates from pyrite in coastal acid sulfate soil environments in Malaysia, Commun. Soil Sci. Plant, 26, 2769-2782, 1995.

Shamshuddin, J., Muhrizal, S., Fauziah, C. I., and Van Ranst, E.: A laboratory study of pyrite oxidation in acid sulfate soils, Commun. Soil Sci. Plant, 35, 117-129, 2004.

Shamshuddin, J., Che Fauziah, I., and Bell, L.C.: Effect of dolomitic limestone and gypsum application on soil solution properties and yield of corn and groundnut grown on ultisols, Malays. J. Soil Sci., 13, 1-12, 2009.

Shamshuddin, J., Elisa Azura, A., Shazana, M. A. R. S., Fauziah, C. I., Panhwar, Q. A., and Naher, U. A.: Properties and management of acid sulfate soils in Southeast Asia for sustainable cultivation of rice, oil palm and cocoa, Adv. Agron., 124, 91-142, 2014.

Shazana, M. A. R. S., Shamshuddin, J., Fauziah, C. I., and Omar, S. R. S.: Alleviating the infertility of an acid sulfate soil by using ground basalt with or without lime and organic fertilizer under submerged condition, Land Degrad. Dev., 24, 129-140, 2013.

Smith, P., Cotrufo, M. F., Rumpel, C., Paustian, K., Kuikman, P. J., Elliott, J. A., McDowell, R., Griffiths, R. I., Asakawa, S., Bustamante, M., House, J. I., Sobocká, J., Harper, R., Pan, G., West, P. C., Gerber, J. S., Clark, J. M., Adhya, T., Scholes, R. J., and Scholes, M. C.: Biogeochemical cycles and biodiversity as key drivers of ecosystem services provided by soils, SOIL, 1, 665685, doi:10.5194/soil-1-665-2015, 2015.

Smyth, T. J. and Sanchez, P. A.: Effects of lime, silicate, and phosphorus application to an oxisol on phosphorus sorption and ion retention, Soil Sci. Soc. Am. J., 44, 500-505, 1980.

Suswanto, T., Shamshuddin, J., Omar, S. R. S., Mat, P., and The, C. B. S.: Alleviating an acid sulfate soil cultivated to rice (Oryza sativa) using ground magnesium limestone and organic fertilizer, J. Tanah Lingkungan, 9, 1-9, 2007.

Tejada, M. and Benifez, C.: Effects of crushed maize straw residues on soil biological properties and soil restoration, Land Degrad. Dev., 25, 501-509, 2014.

van Breemen, N.: Genesis and solution chemistry of acid sulfate soils in Thailand, Pudoc, Wageningen, The Netherlands, 1976.

Wang, H. Q., Zhao, Q., Zeng, D. H., Hu, Y. L., and Yu, Z. Y.: Remediation of a magnesium-contaminated soil by chemical amendments and leaching, Land Degrad. Dev., 26, 613-619, 2015.

Yazdanpanah, N., Mahmoodabadi, M., and Cerda, A.: The impact of organic amendments on soil hydrology, structure and microbial respiration in semiarid lands, Geoderma, 266, 58-65, 2016.

Zhao, X., Wu, P., Gao, X., and Persaud, N.: Soil quality indicators in relation to land use and topography in a small catchment on the Loess Plateau of China, Land Degrad. Dev., 26, 54-61, 2015. 